\title{
Myelopathy in a patient with leukodystrophy due to CSF1R mutation
}

Victoria M. Ho, MD, PhD, Dominic A. Hovsepian, MD, and Perry B. Shieh, MD, PhD

Neurol Genet 2019;5:e376. doi:10.1212/NXG.0000000000000376

\author{
Correspondence \\ Dr. Shieh \\ pshieh@mednet.ucla.edu
}

CSF1R encodes the colony-stimulating factor-1 receptor, a tyrosine kinase that has been identified as one of the main mutations underlying adult-onset leukodystrophy with neuroaxonal spheroids and pigmented glia (ALSP). In the CNS, CSF1R is predominantly expressed in microglia where it plays a role in maintenance and activation of microglia. CSF1R mutations are estimated to account for $10 \%-25 \%$ of adult-onset leukodystrophy, although the actual prevalence is unknown. ${ }^{1}$ The mean age of symptom onset is 48 years, and the average survival is 6.8 years. $^{2}$ Common symptoms include cognitive impairment, personality change, and psychiatric symptoms. ${ }^{1}$ Imaging findings in the brain include bilateral white matter lesions and thinning of the corpus callosum. ${ }^{3}$ Spinal cord involvement is considered atypical. ${ }^{4}$ Here, we present a patient with ALSP who developed spastic paraplegia as her primary initial symptom and had extensive spinal cord abnormalities.

\section{Case report}

A 29-year-old Caucasian woman with a history of migraines presented with bilateral lower extremity paresthesias after a bout of mononucleosis. Her symptoms progressed to bilateral foot drop and bowel and bladder dysfunction. At her evaluation 5 months after symptom onset, examination was notable for increased tone, $3+$ deep tendon reflexes, and upgoing toes in her lower extremities. She began using a cane for ambulation shortly thereafter and was using a walker 18 months after symptom onset. At her clinic follow-up at 30 months after symptom onset, she was wheelchair-dependent and reported that she had stopped her job as a teaching assistant for special needs children because of episodes of incontinence at work. On examination, her lower extremities exhibited severe spasticity, spontaneous clonus, and 0 of 5 strength throughout. She had mild left upper extremity weakness. Examination was additionally notable for dysarthria and a Montreal Cognitive Assessment (MoCA) score of 25 of 30 . At 34 months, motor examination was stable although MoCA performance further deteriorated to 19 of 30 .

Brain imaging at 8 months showed mild signal abnormalities that remained grossly stable on follow-up scans over the next 20 months (figure, A and B, and not shown), while lower extremity, bowel, and bladder symptoms progressed. Spine imaging demonstrated fluidattenuated inversion recovery signal hyperintensities involving the lateral cortical spinal columns of the lower thoracic spine (figure, D). The spinal abnormality spread rostrally over time to involve the cervical spine (figure, $G$ ), and later, the dorsal columns were also involved (figure, $\mathrm{H}$ ). Brain imaging at 30 months demonstrated more prominent signal abnormalities (figure, $\mathrm{E}$ and $\mathrm{F}$ ). None of the lesions enhanced with contrast (not shown).

Laboratory workup for toxic, metabolic, infectious, and autoimmune etiologies was unrevealing with only mild abnormalities in CSF protein $49 \mathrm{mg} / \mathrm{dL}$ (reference $<45 \mathrm{mg} / \mathrm{dL}$ ), plasma antiRo (SSA) 75u (reference $<20 \mathrm{u}$ ), and antinuclear antibody titer 1:80 (reference $<1: 40$ ). Nerve conduction studies were normal. Given prominent lower extremity weakness and spasticity, a hereditary spastic paraplegia gene panel was sent but did not yield any causative mutations. 

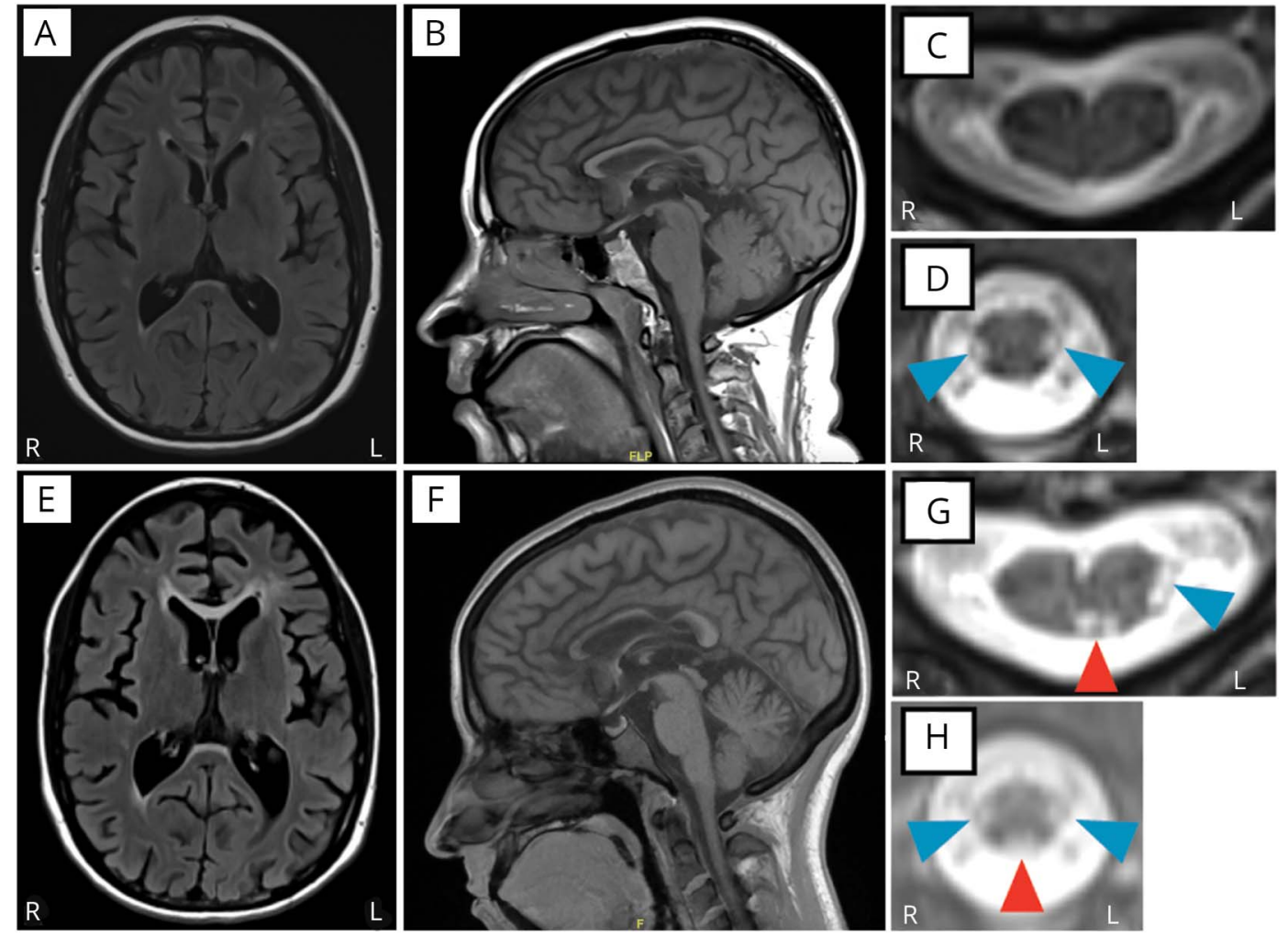

(A and B) At 8 months, frontally predominant, subcortical, and periventricular FLAIR hyperintensities were present in the bilateral white matter and also involved the undersurface of the corpus callosum. There was evidence of mild generalized cerebral volume loss. (C) Cervical spine imaging was unremarkable. (D) Thoracic spine imaging demonstrated bilateral T2 signal hyperintensity within the lateral corticospinal tracts (blue arrowheads) involving the mid to lower thoracic cord. (E and F) At 30 months, brain imaging demonstrated new and more prominent subcortical and periventricular white matter FLAIR signal hyperintensities and progression in FLAIR signal hyperintensity in the corpus callosum including diffuse involvement of the genu. (G) Cervical spine imaging demonstrated new T2 signal hyperintensity involving the lateral cortical spinal tracts (blue arrowheads) and dorsal columns (red arrowhead), extending from C2-3 into the thoracic cord. The spinal cord appears diffusely atrophic. (H) Thoracic spine imaging demonstrated T2 signal hyperintensity involving the lateral cortical spinal tracts (blue arrowheads) and dorsal columns (red arrowhead). The cord appears diffusely atrophic. FLAIR = fluid-attenuated inversion recovery.

The patient was adopted at birth, and her family history was initially unknown. Her adoptive parents were later able to track down her biological family and discovered that her biological mother was residing at a nursing facility with presumed leukodystrophy. Subsequently, a leukodystrophy gene panel revealed a pathogenic, heterozygous missense mutation in CSF1R (c.1765 G>A, p.Gly589Arg) in the patient. Her biological mother was tested and found to have the same mutation. She reportedly developed dysarthria as her earliest symptom at the age of 45 years and subsequently developed dysphagia, bowel/bladder dysfunction, gait impairment, cognitive impairment, and epilepsy.

\section{Discussion}

Despite the infrequency of spinal cord involvement in ALSP, the patient described here had deficits localizing to the lower spine for the first 30 months of her disease course. On imaging, there was early abnormality in the lateral corticospinal tracts in the thoracic spine. The lesions progressed to involve the cervical spine and dorsal column tracts as well, suggesting a disease process occurring locally within the spine. Although
Wallerian degeneration may lead to corticospinal tract involvement, it would not account for dorsal column involvement in the absence of a caudal lesion.

Our patient did not develop the neuropsychiatric symptoms typical of ALSP until later in her disease, formally meeting diagnostic criteria for definite ALSP due to CSF1R mutation at 30 months after symptom onset. ${ }^{5}$ This case highlights the importance of considering leukodystrophy when evaluating myelopathy and the considerable phenotypic variability seen in patients with ALSP. ${ }^{6}$ Although there has been 1 case report of a patient who achieved disease stability after receiving a bone marrow transplant, ${ }^{7}$ there are currently no established therapies for ALSP. A correct diagnosis would help avoid treatments such as immunosuppression, which would not be beneficial and could potentially be detrimental, given the microglial dysfunction already present with CSF $1 R$ mutations.

\section{Author contributions}

V.M.H.: Drafting/revising the manuscript for content, major role in the acquisition of data, and analysis or interpretation of 
data. D.A.H. and P.B.S.: Drafting/revising the manuscript for content, including medical writing for content; major role in the acquisition of data; study concept or design; and analysis or interpretation of data.

\section{Study funding}

No targeted funding reported.

\section{Disclosure}

Disclosures available: Neurology.org/NG.

\section{Publication history}

Received by Neurology: Genetics July 26, 2019. Accepted in final form September 25, 2019.

\section{References}

1. Lynch DS, Jaunmuktane Z, Sheerin UM, et al. Hereditary leukoencephalopathy with axonal spheroids: a spectrum of phenotypes from CNS vasculitis to parkinsonism in an adult onset leukodystrophy series. J Neurol Neurosurg Psychiatry 2016;87: 512-519.

2. Konno T, Kasanuki K, Ikeuchi T, Dickson DW, Wszolek ZK. CSF1R -related leukoencephalopathy. Neurology 2018;91:1092-1104

3. Sundal C, Van Gerpen JA, Nicholson AM, et al. MRI characteristics and scoring in HDLS due to CSF1R gene mutations. Neurology 2012;79:566-574.

4. Keegan BM, Giannini C, Parisi JE, Lucchinetti CF, Boeve BF, Josephs KA. Sporadic adult-onset leukoencephalopathy with neuroaxonal spheroids mimicking cerebral MS. Neurology 2008;70:1128-1133.

5. Konno T, Yoshida K, Mizuta I, et al. Diagnostic criteria for adult-onset leukoencephalopathy with axonal spheroids and pigmented glia due to CSF1R mutation. Eur J Neurol 2018;25:142-147.

6. Sundal C, Lash J, Aasly J, et al. Hereditary diffuse leukoencephalopathy with axonal spheroids (HDLS): a misdiagnosed disease entity. J Neurol Sci 2012;314:130-137.

7. Eichler FS, Li J, Guo Y, et al. CSF1R mosaicism in a family with hereditary diffuse leukoencephalopathy with spheroids. Brain 2016;139:1666-1672. 


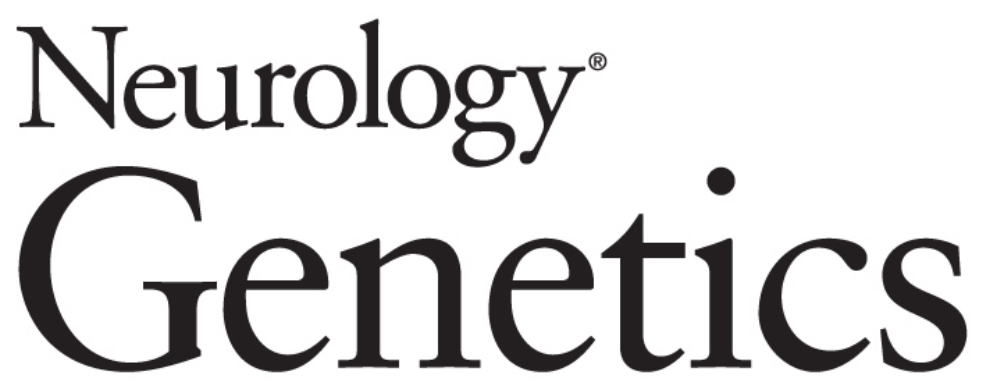

Myelopathy in a patient with leukodystrophy due to $\operatorname{CSF} 1 R$ mutation Victoria M. Ho, Dominic A. Hovsepian and Perry B. Shieh Neurol Genet 2019;5;

DOI 10.1212/NXG.0000000000000376

This information is current as of November 8, 2019

Neurol Genet is an official journal of the American Academy of Neurology. Published since April 2015, it is an open-access, online-only, continuous publication journal. Copyright Copyright $\odot 2019$ The Author(s). Published by Wolters Kluwer Health, Inc. on behalf of the American Academy of Neurology.. All rights reserved. Online ISSN: 2376-7839.

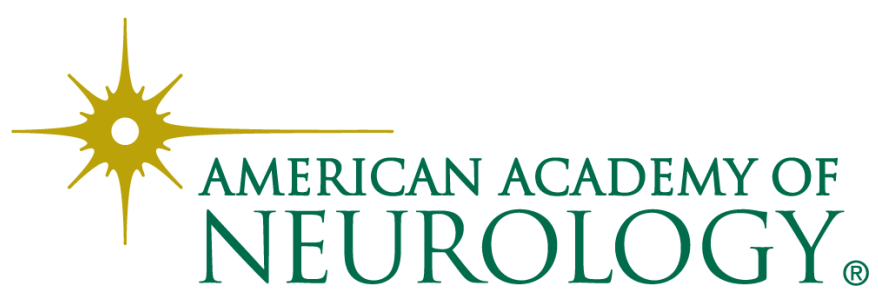




\section{Updated Information \& Services}

References

Subspecialty Collections

Permissions \& Licensing

Reprints including high resolution figures, can be found at:

http://ng.neurology.org/content/5/6/e376.full.html

This article cites 7 articles, 1 of which you can access for free at: http://ng.neurology.org/content/5/6/e376.full.html\#\#ref-list-1

This article, along with others on similar topics, appears in the following collection(s):

\section{All Cognitive Disorders/Dementia}

http://ng.neurology.org//cgi/collection/all_cognitive_disorders_dementi a

\section{All Genetics}

http://ng.neurology.org//cgi/collection/all_genetics

\section{All Spinal Cord}

http://ng.neurology.org//cgi/collection/all_spinal_cord

Leukodystrophies

http://ng.neurology.org//cgi/collection/leukodystrophies

Spastic paraplegia

http://ng.neurology.org//cgi/collection/spastic_paraplegia

Information about reproducing this article in parts (figures,tables) or in its entirety can be found online at:

http://ng.neurology.org/misc/about.xhtml\#permissions

Information about ordering reprints can be found online:

http://ng.neurology.org/misc/addir.xhtml\#reprintsus

Neurol Genet is an official journal of the American Academy of Neurology. Published since April 2015, it is an open-access, online-only, continuous publication journal. Copyright Copyright $\odot 2019$ The Author(s). Published by Wolters Kluwer Health, Inc. on behalf of the American Academy of Neurology.. All rights reserved. Online ISSN: 2376-7839.

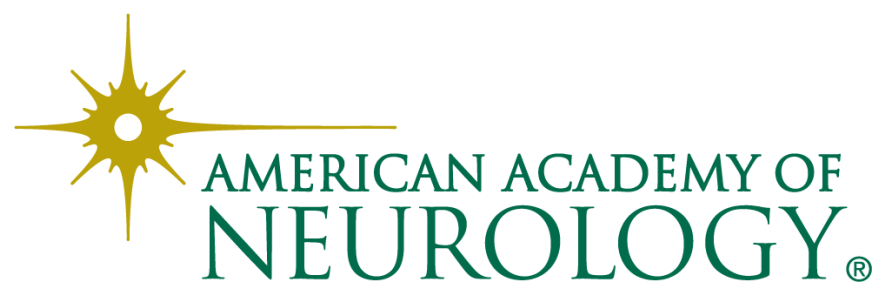

